\title{
Polycystic ovaries-urethral sphincter dysfunction syndrome
}

INSERM

\section{Source}

INSERM. (1999). Orphanet: an online rare disease and orphan drug data base. Polycystic ovaries-urethral sphincter dysfunction syndrome. ORPHA:2795

Polycystic ovaries-urethral sphincter dysfunction syndrome is characterised by urinary retention and incomplete emptying of the bladder associated with abnormal electromyographic activity. It has been described in 33 women, 14 of whom also had polycystic ovaries. 